\title{
Serum and tissue positivity for hepatitis $B$ virus markers in histopathologically proven glomerulonephropathies
}

\author{
S. P. THYAGARAJAN, T. THIRUNALASUNDARI, S. SUBRAMANIAN, M. PANCHANADAM*, \\ B. R. NAMMALWART, V. PRABHAT, VIJAYAKUMAR $\ddagger$ and MUTHU JAYARAMAN $\ddagger$
}

Departments of Microbiology, Dr ALM PG Institute of Basic Medical Sciences, University of Madras, Taramani, Madras 600 113, "Pathology, Kilpauk Medical College, and †Nephrology, Institute of Child Health and Hospital for Children, and $\ddagger$ Stanley Medical College, Madras, India

\begin{abstract}
Summary. To assess the pathogenic significance of hepatitis B virus (HBV) in glomerulonephritis (GN), 98 patients with histopathologically proven glomerulonephropathies were screened for HBV markers, complement components and levels of circulating immune complexes (CICs); and renal biopsies from 31 of them were examined for the presence of hepatitis B surface antigen (HBsAg), and its location, by immunoperoxidase staining. The HBsAg positive rate in the patients (who came from a population with $10 \% \mathrm{HBsAg}$ positivity) ranged from $51.9 \%$ in minimum change nephrotic syndrome (MCNS) to $81.8 \%$ in patients with proliferative glomerulonephritis (PGN). Whereas $24.5 \%$ of the cases were positive for $\mathrm{HBs} A \mathrm{~g}$ only, $10.2 \%$ had anti-HBcIgM with $\mathrm{HBsAg}, 13.3 \%$ had $\mathrm{HBeAg}$ with $\mathrm{HBsAg}$ and $9.2 \%$ had $\mathrm{HBsAg}, \mathrm{HBeAg}$ and anti-HBcIgM. Complement component $\mathrm{C} 3$ levels were decreased in all groups of GN studied, but $\mathrm{C} 4$ levels varied. CIC levels were significantly increased ( $p<0.01$ ) only in HBsAg-positive MCNS, focal glomerulosclerosis (FGS) and membranous glomerulonephritis (MGN). Of the 31 renal biopsies examined for the deposition of $\mathrm{HBsAg}, 4(12.9 \%)$ were found to be positive for HBsAg in situ; $64.5 \%$ of biopsied patients were seropositive for $\mathrm{HBsAg}$ and $77.4 \%$ had CICs. All the four in-situ HBsAg-positive cases were seropositive for $\mathrm{HBsAg}$, $\mathrm{HBeAg}$ and anti-HBcIgM with significantly high CIC levels $(\mathrm{p}<0.01)$. HBsAg deposition was intracytoplasmic in the mesangial cells of the glomeruli, in the glomerular basement membrane or in the tubules, or in a combination of these sites.
\end{abstract}

\section{Introduction}

The association between hepatitis B virus (HBV) infection and membranous glomerulonephropathy was first reported by Combes et al. (1971). Since then there have been several reports (Takekoshi et al., 1978; Slusarczyk et al., 1980; Levy et al., 1982; Hsu et al., 1983); all, except our own (Thyagarajan et al., 1985), were from countries other than India. To define more precisely the extent of the association of HBV with glomerulonephropathies (GN) and the pathogenic significance of such association, we examined 98 histopathologically proven cases of $\mathrm{GN}$ for $\mathrm{HBV}$ markers ( $\mathrm{HBsAg}, \mathrm{HBeAg}$, anti$\mathrm{HBcIgM}$, anti-HBs and anti-HBe), complement components and circulating immune complexes (CICs) in the serum and in some of our patients for in-situ HBsAg in renal biopsies.

Received 20 June 1988; revised version accepted 20 Dec. 1988.

\section{Materials and methods}

\section{Patients}

A total of 98 patients attending the nephrology departments of the Institute of Child Health and Hospital for Children, Madras and Government Stanley Hospital, Madras was studied. As well as clinical characterisation, they were confirmed histopathologically by the procedure of Anderson and Kissane (1977) as cases of minimum change nephrotic syndrome (MCNS) 27, membranous glomerulonephritis (MGN) five, membranoproliferative glomerulonephritis (MPGN) 18, diffuse proliferative glomerulonephritis (DPGN) 15, focal glomerular sclerosis (FGS) 13, and proliferative glomerulonephritis (PGN) 11. The remaining nine cases included crescentic glomerulonephritis (CGS), transplanted kidneys with chronic rejection, and others. Also included in the study were 106 ( 20 children and 86 adults) apparently healthy, controls of similar age and sex distribution. 


\section{Serum markers}

Serum samples from all these patients were screened for HBV markers (HBsAg, $\mathrm{HBeAg}$, anti-HBcIgM, antiHBs and anti-HBe) by ELISA with commercial kits (Hoechst Pharmaceuticals India Ltd, and Abbott Laboratories, Chicago). Complement components $\mathrm{C} 3$ and $\mathrm{C} 4$ were estimated by the single radial immunodiffusion (SRID) method of Mancini et al. (1965). Circulating immune complex (CIC) levels were measured by the polyethylene glycol (PEG) precipitation technique of Haskova et al. (1978); CICs were precipitated with PEG $4 \cdot 16 \%(\mathrm{~g} / 100 \mathrm{ml}$ of distilled water $)$ and measured spectrophotometrically; the $O D$ readings gave a $P E G$ index which was multiplied by 100 to give a PEG percentage measurement of CIC levels in comparison with the levels in normal controls (100 PEG\%).

\section{Biopsies}

As the original renal biopsy blocks from 67 of the patients were not available, only 31 of them (MCNS seven, MGN four, DPGN eight, MPGN eight, FGS two and transplant kidney with chronic rejection two) could be examined for the presence of HBsAg in situ by the immunoperoxidase method, with the universal immunoperoxidase staining kit supplied by Ortho-diagnostics $(\mathrm{P})$ Ltd, India (controls, figs. 1 and 2).

\section{Results}

Of the 98 patients, $56(57 \cdot 1 \%)$ were $\mathrm{HBsAg}$ seropositive. The highest proportion of $\mathrm{HBsAg-}$ positive patients was found amongst those with MGN $(80.0 \%)$ and PGN $(81.8 \%)$, whereas fewer of those with FGS $(61.5 \%)$, DPGN $(60.0 \%)$, MCNS $(51.9 \%)$ and others were seropositive (table I). The

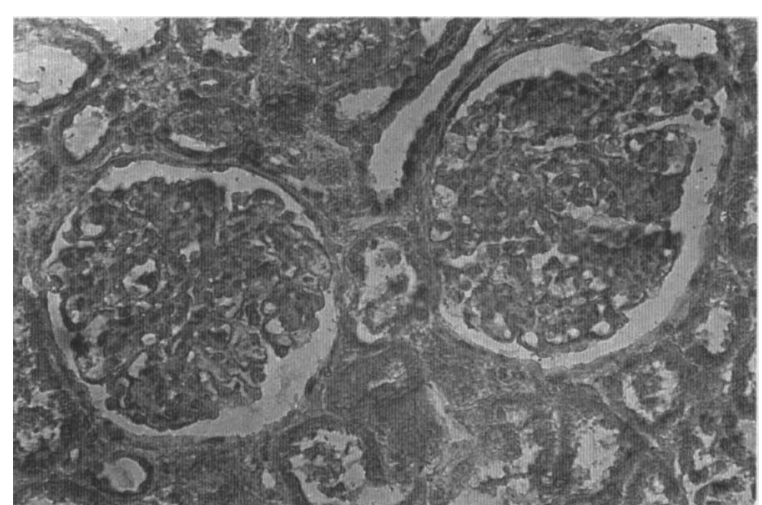

Fig. 1. Biopsy no. $306(344 \times)$. Kidney biopsy section showing two glomeruli without immunoperoxidase positivity-negative control.

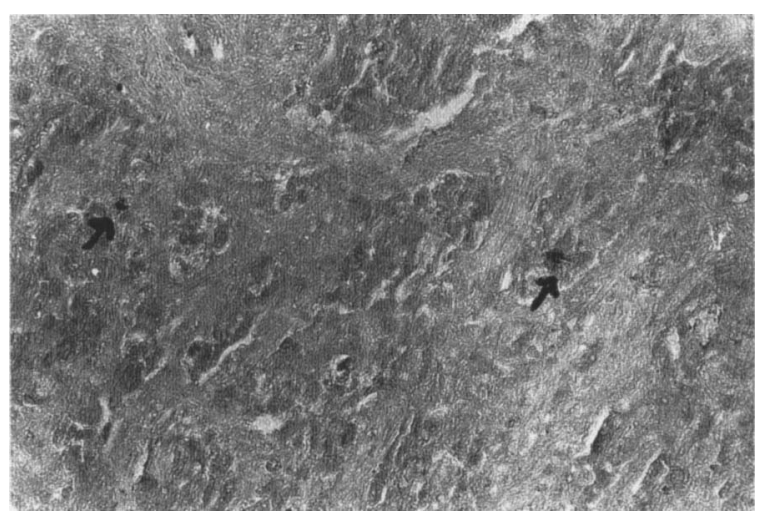

Fig. 2. Biopsy no. L.B. $(215 \times)$. Biopsy section of hepatoma liver showing immunoperoxidase positivity for $\mathrm{HBsAg-positive}$ control.

Table I. Occurrence of HBsAg in renal disorders by histopathological classification

\begin{tabular}{|c|c|c|c|c|c|c|c|}
\hline \multirow[b]{2}{*}{$\begin{array}{l}\text { Patient } \\
\text { group }\end{array}$} & \multirow[b]{2}{*}{$\begin{array}{l}\text { Histopathological } \\
\text { condition }\end{array}$} & \multicolumn{2}{|c|}{ Children } & \multicolumn{2}{|c|}{ Adults } & \multicolumn{2}{|c|}{ Total } \\
\hline & & $\begin{array}{l}\text { Number } \\
\text { tested }\end{array}$ & $\begin{array}{l}\text { HBsAg } \\
\text { positive }\end{array}$ & $\begin{array}{c}\text { Number } \\
\text { tested }\end{array}$ & $\begin{array}{l}\text { HBsAg } \\
\text { positive }\end{array}$ & $\begin{array}{l}\text { Number } \\
\text { tested }\end{array}$ & $\begin{array}{l}\text { HBsAg } \\
\text { positive }\end{array}$ \\
\hline A & $\begin{array}{l}\text { Minimum change nephrotic syndrome } \\
\text { (MCNS) }\end{array}$ & 13 & 6 & 14 & 8 & 27 & 14 \\
\hline B & Focal glomerulosclerosis (FGS) & 8 & 5 & 5 & 3 & 13 & 8 \\
\hline C & Membranous glomerulonephritis (MGN) & 1 & $\mathbf{0}$ & 4 & 4 & 5 & 4 \\
\hline D & $\begin{array}{l}\text { Membranoproliferative glomerulonephri- } \\
\text { tis (MPGN) }\end{array}$ & 10 & 5 & 8 & 2 & 18 & 7 \\
\hline $\mathbf{E}$ & $\begin{array}{l}\text { Diffuse proliferative glomerulonephritis } \\
\text { (DPGN) }\end{array}$ & 8 & 5 & 7 & 4 & 15 & 9 \\
\hline $\mathbf{F}$ & Proliferative glomerulonephritis (PGN) & 8 & 7 & 3 & 2 & 11 & 9 \\
\hline G & Crescentic glomerulonephritis (CGN) & $\mathbf{0}$ & 0 & 3 & 1 & 3 & 1 \\
\hline $\mathbf{H}$ & Miscellaneous group & 0 & 0 & 6 & 4 & 6 & 4 \\
\hline Total & & 48 & 28 & 50 & 28 & 98 & 56 \\
\hline
\end{tabular}


percentage of HBsAg-positive patients was approximately the same in children and adults. Of the 106 controls one of 20 children and 7 of 86 adults were seropositive for $\mathrm{HBsAg}$ only.

Testing the patients' sera for the other HBV markers showed that $24.5 \%$ had HBsAg only, $10 \cdot 2 \%$ had anti-HBcIgM and $\mathrm{HBsAg}, 13 \cdot 3 \%$ had $\mathrm{HBeAg}$ and $\mathrm{HBsAg}$, and $9.2 \%$ had $\mathrm{HBsAg}, \mathrm{HBeAg}$ and anti-HBcIgM. Interestingly only $4.1 \%$ of the patients had anti-HBs and $2.0 \%$ had anti-HBe as well as anti-HBs (table II).

Estimation of complement components (C3 and C4) and $\mathrm{CIC}$ levels revealed that the $\mathrm{C} 3$ level was decreased in all histopathological groups of $\mathrm{GN}$; C4 was significantly decreased in HBsAg-positive PGN and FGS $(p<0.01)$ and increased in HBsAgpositive DPGN. Similarly a significant decrease of $\mathrm{C} 4$ was seen in $\mathrm{HBs} \mathrm{Ag}$-negative MGN and DPGN, whereas in HBsAg-negative MPGN it was the same as in controls and higher than in HBsAgpositive MPGN $(\mathrm{p}<0.01)$ (table III).

CIC levels were increased only in $\mathrm{HBsAg}$ positive MCNS, FGS, MGN and CGN cases ( $\mathrm{p}<$ 0.01 ) whereas MPGN, DPGN and PGN cases had low levels of CICs whether they were HBsAgpositive or -negative.

To study the association of HBV with GN in the kidney, and the pathogenic significance of such association, renal biopsies from 31 patients were examined for the presence of immune complexes (IIC) specific for HBsAg in situ by the immunoperoxidase technique with paraffin sections. Serum HBsAg status and levels of CICs are correlated with the finding of IIC in table IV. Of these 31 cases, $20(64.5 \%)$ were $\mathrm{HBsAg}$ seropositive, 24 $(77.4 \%)$ had increased levels of CICs and four $(12.9 \%)$ had IIC specific for HBsAg. One case each of MGN, DPGN, MPGN and transplanted kidney with chronic rejection had IIC, HBsAg in serum, and higher levels of CIC than did the controls. All these four cases also had $\mathrm{HBeAg}$ and anti-HBcIgM

Table II. HBV markers pattern in 98 histopathologically proven cases of $\mathrm{GN}$

\begin{tabular}{lc}
\hline \multicolumn{1}{c}{ Marker pattern } & $\begin{array}{c}\text { Number (percentage) } \\
\text { positive }\end{array}$ \\
\hline HBsAg alone & $24(24 \cdot 5)$ \\
HBsAg and anti-HBcIgM & $10(10 \cdot 2)$ \\
HBsAg and HBeAg & $13(13 \cdot 3)$ \\
HBsAg, HBeAg and anti-HBcIgM & $9(9 \cdot 2)$ \\
Anti-HBs & $4(4 \cdot 1)$ \\
Anti-HBs and anti-HBe & $2(2 \cdot 0)$ \\
\hline
\end{tabular}

in their sera and none of them had either anti-HBs or anti-HBe (table V).

Sections stained by the immunoperoxidase method and examined by light microscopy showed, in these four cases, HBsAg in the glomeruli (probably mesangial cells), glomerular basement membrane (GBM) and in the tubules, either singly or in combination (figs. 3-6).

\section{Discussion}

In recent years the possibility of a pathogenic role for $\mathrm{HBV}$ in glomerulonephropathies has been reported frequently. These reports have stressed the common association of $\mathrm{HBV}$ infection with two types of glomerular diseases-MGN and MPGN

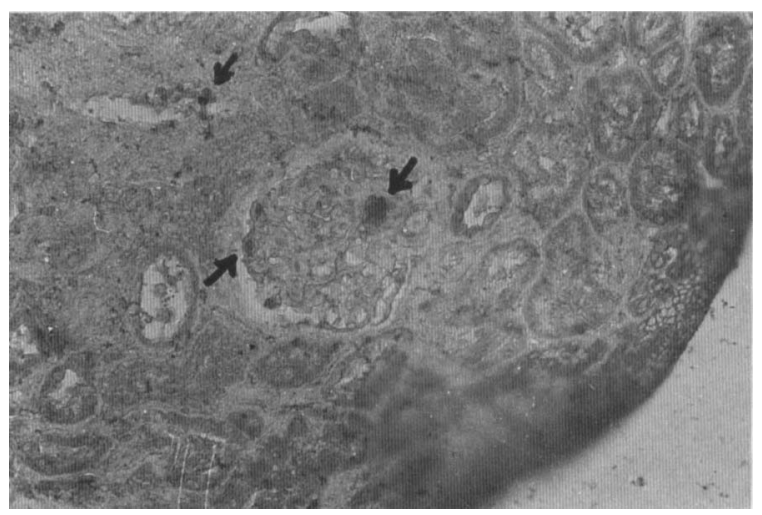

Fig. 3. Biopsy no. $1179(215 \times)$. Renal biopsy section showing immunoperoxidase positivity, arrowed, for $\mathrm{HBsAg}$ in the mesangial cells of the glomeruli and tubules.

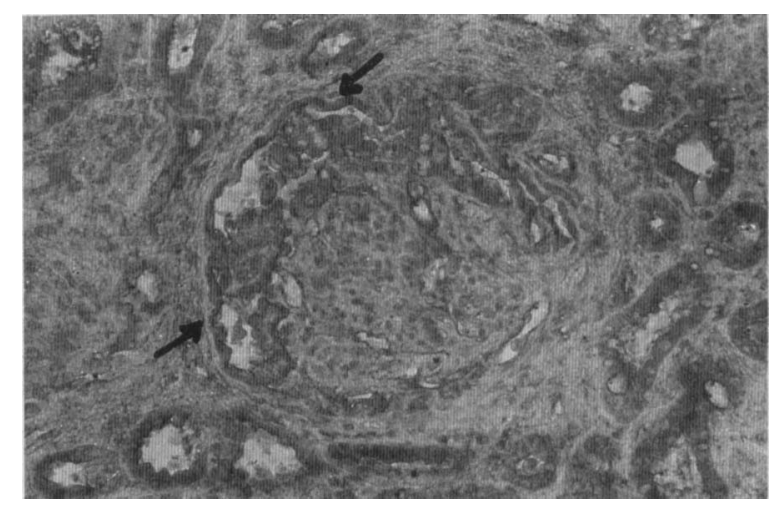

Fig. 4. Biopsy no. $1696(215 \times)$. Renal biopsy section showing immunoperoxidase positivity, arrowed, for $\mathrm{HBsAg}$ in the glomerular basement membrane and mesangial cells of the glomeruli and tubules. 
Table III. Serum complement components (C3, C4) and circulating immune complex (CIC) levels in 48 children and 5 adults with histopathologically classified renal disorder

\begin{tabular}{|c|c|c|c|c|}
\hline \multirow{2}{*}{$\begin{array}{l}\text { Histopathological con- } \\
\text { dition and serum } \\
\text { HBsAg status }\end{array}$} & \multirow{2}{*}{$\begin{array}{l}\text { Number } \\
\text { tested }\end{array}$} & \multicolumn{2}{|c|}{$\begin{array}{l}\text { Mean (SD) complement compo- } \\
\text { nent levels mg/dl }\end{array}$} & \multirow{2}{*}{$\begin{array}{l}\text { Mean (SD) } \\
\text { CIC level } \\
\text { (PEG \%) }\end{array}$} \\
\hline & & $\mathrm{C} 3$ & $\mathrm{C} 4$ & \\
\hline \multicolumn{5}{|l|}{ MCNS } \\
\hline HBsAg-positive & 14 & $\begin{array}{c}36.2(11.8) \\
{ }^{*} p<0.1\end{array}$ & $\begin{array}{c}33.8(9 \cdot 6) \\
* \text { NS }\end{array}$ & $\begin{array}{c}178.7(96.6) \\
{ }^{*} \mathrm{p}<0.01\end{array}$ \\
\hline HBsAg-negative & 13 & $\begin{array}{l}35 \cdot 8(9 \cdot 7) \\
\quad+\mathrm{NS}\end{array}$ & $\begin{array}{l}33.9(21 \cdot 2) \\
\quad \nmid N S\end{array}$ & $\begin{array}{c}111 \cdot 5(69 \cdot 6) \\
+\mathrm{p}<0 \cdot 10\end{array}$ \\
\hline \multicolumn{5}{|l|}{ FGS } \\
\hline HBsAg-positive & 8 & $\begin{array}{c}34.4(12.6) \\
{ }^{*} p<0.01\end{array}$ & $\begin{array}{c}16.5(10.4) \\
{ }^{*} p<0.01\end{array}$ & $\begin{array}{c}215.8(68.1) \\
{ }^{*} \mathrm{p}<0.01\end{array}$ \\
\hline HBsAg-negative & 5 & $\begin{array}{l}40 \cdot 9(5 \cdot 5) \\
+\mathrm{NS}\end{array}$ & $\begin{array}{l}24 \cdot 3(10 \cdot 9) \\
\quad+N S\end{array}$ & $\begin{array}{c}121.0(33.8) \\
t p<0.01\end{array}$ \\
\hline \multicolumn{5}{|l|}{ MGN } \\
\hline HBsAg-positive & 4 & $\begin{array}{l}48.9(13.9) \\
* \mathrm{p}<0.01\end{array}$ & $\begin{array}{l}38 \cdot 3(12 \cdot 7) \\
* \text { NS }\end{array}$ & $\begin{array}{c}298.0(94 \cdot 2) \\
{ }^{*} \mathrm{p}<0.01\end{array}$ \\
\hline HBsAg-negative & 1 & $40 \cdot 9$ & $21 \cdot 3$ & $127 \cdot 8$ \\
\hline $\begin{array}{l}\text { MPGN } \\
\text { HBsAg-positive }\end{array}$ & 7 & $\begin{array}{c}48.4(20.9) \\
{ }^{*} p<0.01\end{array}$ & $\begin{array}{c}21 \cdot 9(11 \cdot 2) \\
\quad * N S\end{array}$ & $\begin{array}{c}109 \cdot 3(72 \cdot 4) \\
* \mathrm{NS}\end{array}$ \\
\hline HBsAg-negative & 11 & $\begin{array}{l}40 \cdot 8(2 \cdot 7) \\
+\mathrm{NS}\end{array}$ & $\begin{array}{l}32.9(9.5) \\
+\mathrm{p}<0.05\end{array}$ & $\begin{array}{l}96 \cdot 1(75 \cdot 8) \\
\quad+N S\end{array}$ \\
\hline \multicolumn{5}{|l|}{ DPGN } \\
\hline HBsAg-positive & 9 & $\begin{array}{l}35.6(13.3) \\
{ }^{*} \mathrm{p}<0.01\end{array}$ & $\begin{array}{l}38.5(11.9) \\
{ }^{*} \mathrm{p}<0.05\end{array}$ & $\begin{array}{l}113 \cdot 9(81 \cdot 1) \\
{ }^{* N S}\end{array}$ \\
\hline HBsAg-negative & 6 & $\begin{array}{l}38 \cdot 7(1 \cdot 3) \\
+\mathrm{NS}\end{array}$ & $\begin{array}{l}18.8(3.7) \\
\dagger \mathrm{p}<0.01\end{array}$ & $\begin{array}{l}132 \cdot 8(53 \cdot 3) \\
\quad \nmid N S\end{array}$ \\
\hline \multicolumn{5}{|l|}{ PGN } \\
\hline HBsAg-positive & 9 & $\begin{array}{l}40.0(1 \cdot 1) \\
{ }^{*} p<0.01\end{array}$ & $\begin{array}{l}17.5(3.7) \\
{ }^{*} \mathrm{p}<0.01\end{array}$ & $\begin{array}{l}108 \cdot 7(74.9) \\
\quad * \text { NS }\end{array}$ \\
\hline HBsAg-negative & 2 & $\begin{array}{l}42 \cdot 7(6 \cdot 1) \\
\dagger N S\end{array}$ & $\begin{array}{c}25.8(6.6) \\
+\mathrm{NS}\end{array}$ & $\begin{array}{l}136 \cdot 1(2 \cdot 2) \\
\quad+N S\end{array}$ \\
\hline \multicolumn{5}{|l|}{ CGN } \\
\hline $\begin{array}{l}\text { HBsAg-positive } \\
\text { HBsAg-negative }\end{array}$ & $\begin{array}{l}1 \\
2\end{array}$ & $\begin{array}{c}36 \cdot 2 \\
51 \cdot 1(4 \cdot 1)\end{array}$ & $\begin{array}{c}28 \\
28 \cdot 3(3 \cdot 7)\end{array}$ & $\begin{array}{c}221 \cdot 0 \\
60 \cdot 4(15 \cdot 6)\end{array}$ \\
\hline \multicolumn{5}{|l|}{ Miscellaneous cases } \\
\hline HBsAg-positive & 4 & $\begin{array}{l}43.6(2.8) \\
* \mathrm{p}<0.01\end{array}$ & $\begin{array}{c}21 \cdot 8(11 \cdot 2) \\
* \mathrm{NS}\end{array}$ & $\begin{aligned} 243.9 & (11.4) \\
{ }^{*} \mathrm{p} & <0.01\end{aligned}$ \\
\hline HBsAg-negative & 2 & $\begin{array}{l}30 \cdot 5(10 \cdot 5) \\
+\mathrm{NS}\end{array}$ & $\begin{array}{l}15 \cdot 8(1 \cdot 9) \\
\quad \nmid N S\end{array}$ & $\begin{array}{l}244 \cdot 2(76 \cdot 4) \\
+ \text { NSS }\end{array}$ \\
\hline \multicolumn{5}{|l|}{$\begin{array}{l}\text { Matched controls } \\
\text { Children }\end{array}$} \\
\hline $\begin{array}{l}\text { HBsAg-positive } \\
\text { HBsAg-negative }\end{array}$ & $\begin{array}{r}1 \\
19\end{array}$ & $\begin{array}{c}68 \cdot 4 \\
72 \cdot 8(4 \cdot 6)\end{array}$ & $\begin{array}{c}24 \cdot 8 \\
28 \cdot 2(10 \cdot 2)\end{array}$ & $\begin{array}{c}108 \cdot 2 \\
114 \cdot 4(16 \cdot 4)\end{array}$ \\
\hline \multicolumn{5}{|l|}{ Adults } \\
\hline $\begin{array}{l}\text { HBsAg-positive } \\
\text { HBsAg-negative }\end{array}$ & 9 & $82 \cdot 6(3 \cdot 2)$ & $26 \cdot 7(2 \cdot 2)$ & $105 \cdot 3(7 \cdot 8)$ \\
\hline HBsAg-negative & 77 & $78 \cdot 7(2 \cdot 6)$ & $31 \cdot 3(10 \cdot 8)$ & $112 \cdot 3(8 \cdot 7)$ \\
\hline
\end{tabular}

* HBsAg-positive vs HBsAg-positive controls.

$\dagger$ HBsAg-positive $v s$ HBsAg-negative.

NS $=$ Not significant. 


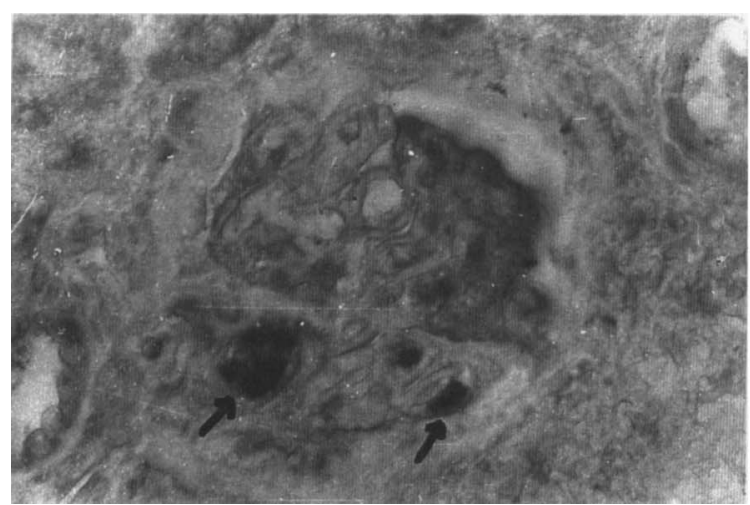

Fig. 5. Biopsy no. $1675(860 \times)$. Renal biopsy section showing immunoperoxidase positivity, arrowed, for $\mathrm{HBs} \mathrm{Ag}$ in the mesangial cells of the glomeruli alone.

(Levy et al., 1982). In our present series we too found the highest prevalence of HBsAg in MGN $(80 \%)$. After the first report of Combes et al. (1971) demonstrating $\mathrm{HBsAg}$ in MGN, several workers reported $\mathrm{HBV}$ markers in $20.6-100 \%$ of $\mathrm{MGN}$ (Takekoshi et al., 1978, 11 of 11; Slusarczyk et al.,

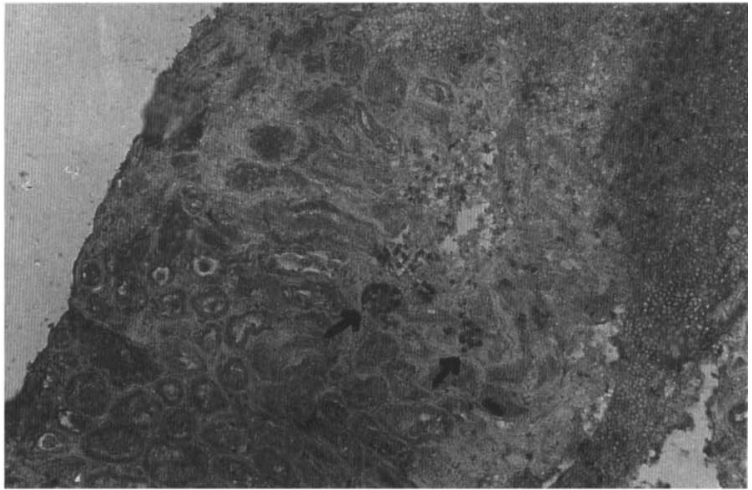

Fig. 6. Biopsy no. $1179(215 \times)$. Renal biopsy section showing immunoperoxidase positivity, arrowed, for $\mathrm{HBsAg}$ in the tubules alone.

1980, 24 of 98; Hsu et al., 1983, 13 of 63, Hirose et al., 1984, 10 of 16).

Besides MGN, as in the present series, MPGN (Knieser et al., 1974; Myers et al., 1973; Slusarczyk et al., 1980; Levy et al., 1982; Lai et al., 1987), FGS, MCNS, diffuse extra capillary and miscellaneous

Table IV. HBsAg, CIC and IIC positivity in histopathologically classified renal disorders

\begin{tabular}{|c|c|c|c|c|c|}
\hline \multirow[b]{2}{*}{$\begin{array}{l}\text { Histopathological } \\
\text { condition }\end{array}$} & \multirow[b]{2}{*}{$\begin{array}{c}\text { Number } \\
\text { tested }\end{array}$} & \multirow[b]{2}{*}{$\begin{array}{l}\text { Serum HBsAg } \\
\text { positive }\end{array}$} & \multicolumn{2}{|c|}{ CIC Level } & \multirow[b]{2}{*}{ IIC positive } \\
\hline & & & $\begin{array}{l}\text { Number } \\
\text { positive }\end{array}$ & $\begin{array}{c}\text { Mean (SD) } \\
\text { PEG \% }\end{array}$ & \\
\hline MCNS & 7 & 2 & 5 & $128 \cdot 7(36 \cdot 5)$ & 0 \\
\hline FGS & 2 & 2 & 2 & $128 \cdot 2(62 \cdot 1)$ & 0 \\
\hline MGN & 4 & 3 & 3 & $292 \cdot 1(68 \cdot 2)$ & 1 \\
\hline DPGN & 8 & 8 & 5 & $183 \cdot 9(21 \cdot 1)$ & 1 \\
\hline MPGN & 8 & 3 & 7 & $118 \cdot 3(27 \cdot 4)$ & 1 \\
\hline Chronic rejection & 2 & 2 & 2 & $222.0(11.4)$ & 1 \\
\hline Total & 31 & $\begin{array}{c}20 \\
(64 \cdot 5 \%)\end{array}$ & $\begin{array}{c}24 \\
(77 \cdot 4 \%)\end{array}$ & $178.8(68.5)$ & $\begin{array}{c}4 \\
(12 \cdot 9 \%)\end{array}$ \\
\hline
\end{tabular}

Table V. HBV markers pattern in IIC-positive patients

\begin{tabular}{lccccccc}
\hline & \multicolumn{7}{c}{ HBV marker positivity } \\
\cline { 2 - 6 } \multicolumn{1}{c}{$\begin{array}{c}\text { Histopathological } \\
\text { condition }\end{array}$} & HBsAg & Anti-HBs & HBeAg & anti-HBe & anti-HBcIgM & IIC & CIC \\
\cline { 2 - 7 } MGN & + & - & + & - & + & + & + \\
MPGN & + & - & + & - & + & + & + \\
DPGN & + & - & + & - & + & + & + \\
Chronic rejection & + & - & + & - & + & + & + \\
\hline
\end{tabular}

$+=$ positive $;-=$ negative . 
groups (Slusarczyk et al., 1980) and IgA nephropathies (Lai et al., 1987) have also been shown to be associated with $\mathrm{HBs}$ antigenaemia.

Animal experiments and observations on human subjects have demonstrated that $\mathrm{HBV}$-containing immune complexes may be formed in the course of HBV-induced acute and chronic hepatitis (Slusarczyk et al., 1980; Lesavre et al., 1982). Immune complex glomerulonephritis has been reproduced in an experimental model by inoculation of baboons with human HBsAg (Gyorkey et al., 1975) and immune complex glomerulonephritis has been demonstrated in patients with acute hepatitis B infection (Ozawa et al., 1976).

Immune complex-mediated glomerulonephritis is held to require a continuous supply of antigen and a maintained antibody response for development and progression of the disease. Accepting this hypothesis, the finding of increased levels of CICs in our $\mathrm{HBsAg}$-positive GN patients, who are drawn from a population with a high (around $10 \%) \mathrm{HBsAg}$ carriage rate (Thyagarajan et al., 1985), strongly suggests that HBsAg immune complexes contribute to the pathogenesis of glomerulonephritis in such patients; and confirms the conclusions of others (Vos et al., 1973; Furuse et al., 1982).

Demonstration of $\mathrm{HBV}$-specific antigens within the glomeruli has been considered to be strong evidence for the aetiological association of HBV with GN. The present study showed HBsAg deposits in the renal biopsies from only $12.9 \%$ of the cases tested.

Slusarczyk et al. (1980) demonstrated the presence of $\mathrm{HBsAg}$ and $\mathrm{HBeAg}$ and hypothesised that only the low mol. wt components of these antigens might be involved in the formation of immune complexes. Takekoshi et al. (1979) and Hirose et al. (1984) have demonstrated the presence of $\mathrm{HBeAg}$ and suggested that this antigen, whose mol. wt is below $3 \times 10^{3} \mathrm{Kda}$, could easily induce the forma-

\section{REFERENCES}

Anderson W A D, Kissane J M (eds) 1977 In: Pathology, 7th edn, vol. 2. C V Mosby Co., St Louis, pp 1321-1438.

Blaker F, Hellwege H H, Kramer U, Thoenes W 1974 Membranous nephropathy and hepatitis-B antigen. Lancet 2: 955-956.

Brzosko W J, Krawczynski K, Nazarewick T, Morzycka M, Nowoslawski A 1974 Glomerulonephritis associated with hepatitis-B surface antigen immune complexes in children. Lancet 2: 477-482.

Combes B et al. 1971 Glomerulonephritis with deposition of Australia antigen-antibody complexes in glomerular basement membrane. Lancet 2: 234-237.

Furuse A, Hattori S, Terashima T, Karashima S, Matsuda I tion of subepithelial deposits, whereas the deposition of HBsAg, whose mol. wt is high, appeared unlikely. This might also explain the low rate of $\mathrm{HBs} \mathrm{Ag}$ positivity in renal biopsies in this series.

Most workers have reported immunofluorescence (IF) studies of the renal parenchyma (Myers et al., 1973; Brzosko et al., 1974; Knieser et al., 1974) and HBsAg has been demonstrated in association with immunoglobulins along capillary walls or in the mesangium, or both. Glomerular deposits of immune complexes containing $\mathrm{HBs} \mathrm{Ag}$ or $\mathrm{HBeAg}$, or both, were detected in 41,61 and $60 \%$ of cases of membranous nephropathy, IgA nephropathy and MPGN respectively by Lai et al. (1987).

The pattern of immunoperoxidase positivity for $\mathrm{HBs} \mathrm{Ag}$ in renal biopsies, as observed in the present series, has shown $\mathrm{HBsAg}$ deposits in the mesangial cells (intracytoplasmic), GBM and tubules; one or all of these sites being affected. Having reviewed previous reports we find that the only report, apart from this present one, of the demonstration of $\mathrm{HBsAg}$ in paraffin sections by the immunoperoxidase method and light microscopy is that of Lai $e t$ al. (1987). Ours may be the first report to show HBsAg in tubules. Combes et al. (1971), Hsu et al. (1983), Kohler et al. (1974) and Blaker et al. (1974) have demonstrated $\mathrm{HBsAg}$ in the mesangial cells and GBM alone. Even though Slusarczyk et al. (1980) and Knieser et al. (1974) have employed the immunoperoxidase technique, their observations for HBsAg have been by electronmicroscopy.

On the basis of the finding of $\mathrm{HBsAg}, \mathrm{HBeAg}$ and anti-HBcIgM in the IIC (HBsAg) positive cases and the intracytoplasmic localisation of HBsAg in the mesangial cells of the glomeruli, it is tempting to suggest that the kidney is a secondary site of HBV multiplication. However it requires further in-depth electronmicroscopic studies to confirm the present observations.

1982 Circulating immune complexes in glomerulonephropathy associated with hepatitis B Virus infection. Nephron 31 : 212-218.

Gyorkey F et al. 1975 Immune-complex glomerulonephritis, intranuclear particles in hepatocytes and in-vivo clearance rate in sub-human primates inoculated with $\mathrm{HBsAg-}$ containing plasma. Experimental and Molecular Pathology 22: $350-365$.

Haskova V, Kasli K J, Riha K, Matl I, Rovensky J 1978 Simple method of circulating immune-complex detection in human sera by polyethylene glycol precipitation. Zeitschrift für Immunitalsforschung-immunobiology 154: 399-406.

Hirose $\mathbf{H}$ et al. 1984 Deposition of Hepatitis B antigèn in membranous glomerulonephritis: Identification by $\mathrm{F}(\mathrm{ab})_{2}$ fragments of monoclonal antibody. Kidney International 26: 338-341. 
Hsu H C, Lin G H, Chang M H, Chen C H 1983 Association of hepatitis $B$ surface (HBs) antigenemia and membranous nephropathy in children in Taiwan. Clinical Nephrology 20: 121-129.

Knieser M R, Jenis E H, Lowenthal D T, Bancroft W H, Burns W, Shalhoub R 1974 Pathogenesis of renal disease associated with viral hepatitis. Archives of Pathology 97: 193-200.

Kohler P F, Cronin R E, Hammond W S, Olin D, Carr R I 1974 Chronic membranous glomerulonephritis caused by hepatitis B antigen-antibody immune complexes. Annals of Internal Medicine 81 : 448.

Lai K N, Lai F M, Chan K W, Chow C B, Tong K L, Vallance O J 1987 The clinico-pathologic features of Hepatitis B virus-associated glomerulonephritis. Quarterly Journal of Medicine. New series 63: 240: 323-333.

Lesavre P, Digeon M, Bach J F 1982 Analysis of circulating IgA and detection of Immune complexes in primary IgA nephropathy. Clinical and Experimental Immunology 48: 6169.

Levy M, Kleinknecht C, Droz D, Drueke T 1982 Glomerular Nephropathies and Hepatitis B Virus infection. Year Book Medical Publishers, pp 341-370.

Mancini G, Carlonara A O, Heremans J E 1965 Immunocytochemical quantitation of antigens by single radial immunodiffusion. International Journal of Immunochemistry 2: 234-254.

Myers B D, Griffel B, Naveh D, Jankielowitz T, Klajman A
1973 Membrano-proliferative glomerulonephritis associated with persistent viral hepatitis. American Journal of Clinical Pathology 10: 228.

Ozawa T, Levisohn P, Orsini E, McIntosh R M 1976 Acute immune complex disease associated with hepatitis. Etiopathogenic and immunopathogenic studies of the renal lesion. Archives of Pathology and Laboratory Medicine 100: 484-486.

Slusarczyk J, Michalak T, Nazarewicz-De Mezer T, Krawczynski K, Nowoslawski A 1980 Membranous glomerulopathy associated with hepatitis $\mathrm{B}$ core antigen immune complexes in children. American Journal of Pathology 98: 29-43.

Takekoshi Y, Tanaka M, Shida N, Satake Y, Saheki Y, Matsumoto 1978 Strong association between membranous nephropathy and hepatitis B surface antigenaemia in Japanese children. Lancet 2: 1065-1068.

Takekoshi Y, Tanaka M, Miykawa Y, Yoshizawa H, Takahashi, Mayumi M 1979 Free 'small' B e antigen in the serum and glomerular capillary walls and IsG-associated "large" hepatitis in two patients with membranous glomerulonephritis. New England Journal of Medicine 300: 814-819.

Thyagarajan S P et al. 1985 Immunological studies in Hepatitis B Virus. Information Exchange Newsletter (Western Australia) $2: 1: 11-17$.

Vos G H, Grobbelaar B G, Milnet L V 1973 A possible relationship between persistent hepatitis $B$ antigenaemia and renal disease in southern African Bantu. South African Medical Journal 47: 911-912. 